\title{
Identifikasi Karakteristik Reservoar Berdasarkan Data Akuistik Impedan dan Log Neutron Porositas Studi Kasus: Lapangan Boonsville, USA
}

\author{
Febrian Dedi Sastrawan", Irsan Ar Rahman, Rahmania, dan Meidi Arisalwadi \\ Jurusan Sains, Teknologi Pangan dan Kemaritiman, Program Studi Fisika, Institut Teknologi \\ Kalimantan, Balikpapan \\ *Email: Febrian.dedi@itk.ac.id
}

\begin{abstract}
The title of this research is Identification of Reservoir Characteristics Based on Impedant Aquatic Data and Neutron Porosity Logs Case Study: Boonsville Field, USA. This research is motivated by the need to find the location of hydrocarbon prospects in an effort to maintain energy security. The purpose of this study is to obtain clean sand stone $A I$ cutoff values in Caddo and Vineyard formations based on the results of crossplot for $\log A I$, density, and gamma ray and to determine locations/zones predicted to contain hydrocarbons (especially gases) in Caddo and Vineyard formations based on the results of $A I$ inversion analysis, porosity, and qualitative analysis of $\log$ data. The method used in this study is seismic inversion acoustic impedance (AI). Seismic inversion $A I$ method is used to obtain rock physical parameters, namely acoustic impedance so that the distribution of the reservoir zone where stored hydrocarbon reserves can be predicted. The results of $A I$ distribution on seismic volume can be used to predict the distribution of porosity. The prediction of porosity distribution on seismic volume is obtained from the linear regression between $A I$ values and porosity log data on $\mathrm{B}$ Yates $18 \mathrm{D}$. The results showed that the clean sandstone $A I$ cutoff in the Caddo formation was $38000-55500(\mathrm{ft} / \mathrm{s})$ $(\mathrm{gr} / \mathrm{cc})$ and in the Vineyard formation of $33000-37500(\mathrm{ft} / \mathrm{s})(\mathrm{gr} / \mathrm{cc})$. Top Caddo has 4 zones which are predicted to contain gas with a reservoir of clean sand stone. On Top Vineyard found 3 zones also contained gas that is predicted to be shaly sand reservoir.
\end{abstract}

Keywords: acoustic impedance, hydrocarbon, porosity, seismic inversion

\section{ABSTRAK}

Penelitian ini berjudul Identifikasi Karakteristik Reservoar Berdasarkan Data Akuistik Impedan Dan Log Neutron Porositas Studi Kasus: Lapangan Boonsville, USA. Penelitian ini dilatarbelakangi oleh perlunya menemukan lokasi prospek hidrokarbon dalam upaya menjaga ketahanan energi. Tujuan dari penelitian ini antara lain untuk mendapatkan nilai cutoff AI clean sand stone pada formasi Caddo dan Vineyard berdasarkan hasil crossplot log $A I$, density, dan gamma ray dan untuk menentukan lokasi/zona yang di prediksi mengandung hidrokarbon pada formasi Caddo dan Vineyard berdasarkan hasil analisis inversi $A I$, porositas, dan analisis kualitatif data log. Metode yang digunakan dalam penelitian ini adalah metode seismik inversi impedansi akustik $(A I)$. Metode seismik inversi $A I$ digunakan untuk mendapatkan parameter fisis batuan yaitu impedansi akustik sehingga persebaran zona reservoar tempat tersimpannya cadangan hidrokarbon dapat diprediksi. Hasil sebaran $A I$ pada volume seismik dapat digunakan untuk memprediksi sebaran porositas. Prediksi sebaran porositas pada volume seismik didapat dari hasil regresi linier antara nilai $A I$ dengan data $\log$ porositas pada sumur $\mathrm{B}$ Yates 18 D. Hasil penelitian didapatkan nilai cutoff AI clean sand stone pada formasi Caddo sebesar $38000-55500(\mathrm{ft} / \mathrm{s})(\mathrm{gr} / \mathrm{cc})$ dan pada formasi Vineyard sebesar $33000-37500(\mathrm{ft} / \mathrm{s})(\mathrm{gr} / \mathrm{cc})$. Pada Top Caddo memiliki 4 zona yang diprediksi mengandung gas dengan reservoar berupa clean sand stone. Pada Top Vineyard ditemukan 3 zona yang diprediksi juga mengandung gas dengan reservoar berupa shaly sand.

Kata Kunci: impedansi akustik, hidrokarbon, porositas, inversi seismik 


\section{PENDAHULUAN}

Pencarian lokasi prospek hidrokarbon di daerah Lapangan Boonsville, USA sangat dibutuhkan dalam upaya menjaga ketahanan energi. Kebutuahan sumber daya minyak dan gas bumi yang semakin meningkat dan terbatasnya ketersediaannya menyebabkan perlunya dilakukan pengoptimalisasian lapangan - lapangan tua yang telah mengalami penurunan produksi.berbagai hal dapat dilakukan dengan cara menganalisis lebih lanjut data seismic dan data log yang ada untuk mengetahui zona prosepek hidrokarbon. Salah satu proses yang dapat digunakan untuk melakukan pencarian zona prospek hidrokarbon adalah karakterisasi reservoir berdasarkan data seismic dan data log neutron. Karakterisasi reservoar adalah suatu proses untuk mendeskripsikan secara kualitatif dan kuantitatif karakter reservoar dengan menggunakan data seismik dan data $\log ^{[1]}$ Parameter reservoar seperti litologi, porositas, dan fluida pengisi dapat diketahui melalui karakterisasi reservoar.

Metode yang dapat digunakan untuk melakukan karakterisasindata seismic adalah metode seismik inversi. Russell mendefinisikan metode seismik inversi baik yang menggunakan data seismik post-stack maupun pre-stack sebagai suatu teknik untuk membuat model bawah permukaan dengan menggunakan data seismik sebagai input dan data sumur sebagai kontrol. Data seismik memiliki resolusi horizontal yang cukup baik tetapi resolusi vertikal relatif buruk. Sebaliknya data sumur memiliki resolusi vertikal yang cukup baik tetapi resolusi horizontal relatif buruk ${ }^{[2]}$. Integrasi keduanya memberikan hasil yang efektif dan efisien dalam karakterisasi reservoar. Contoh hasil inversi seismik yang menggabungkan data seismik dan data sumur adalah inversi impedansi akustik (AI). Data seismik hanya melihat objek bawah permukaan dalam bentuk bidang batas antar lapisan batuan yang memiliki perbedaan nilai impedansi akustik. Hasil inversi AI yang menggabungkan wavelet hasil ekstraksi dari data seismik post-stack dengan koefisien refleksi dari data sumur mampu melihat objek bawah permukaan berdasarkan nilai impedansi akustik yang dimiliki oleh lapisan tersebut. Selanjutnya apabila korelasi antara hasil inversi AI dengan data sumur cukup baik maka inversi AI dapat dilakukan di seluruh volume seismik. Nilai impedansi akustik pada volume seismik digunakan untuk menentukan persebaran reservoar atau lapisan permeable tempat tersimpannya cadangan hidrokarbon ${ }^{[3]}$. Parameter lain yang diperoleh dari nilai impedansi akustik pada volume seismik adalah porositas ${ }^{[4]}$. Besar porositas batuan pada volume seismik dapat diprediksi dengan menggunakan hubungan regresi linier antara nilai AI dengan data log porositas sehingga dapat ditentukan lokasi batuan reservoar yang memiliki porositas besar/kecil ${ }^{[5]}$.berdasarkan uraian diatas perlu dilakukan kajian tentang korelasi antara Impedansi Akustik dan porositas batuan berdasarkan log Neutron untuk mengetahui lokasi prosespek Hidrokarbon didaerah penelitian.

Penelitian ini menggunakan data seismik 3D post-stack dan 38 sumur dengan dua buah sumur di antaranya memiliki log AI dan satu sumur yang memiliki log porositas. Data penelitian ini merupakan data sekunder yang didapat dari Bureau of Economic Geology Texas. Interpretasi hasil penelitian ini dapat digunakan sebagai bahan acuan dan menjadi rekomendasi dalam pengembangan lapangan Boonsville, Texas USA.

\section{METODE}

Pada penelitian ini digunakan dua data yaitu data seismik dan data $\log$. Data seismik yang digunakan dalam penelitian ini merupakan data sekunder yang didapat dari badan Bureau of Economic Geology Texas, USA. Besar wilayah seismik dalam koordinat lokal yang digunakan dalam penelitian ini berkisar antara inline (74-206) dan xline (105-201) seperti yang ditampilkan pada Gambar 1. 
Data $\log$ yang digunakan pada penelitian ini merupakan data sekunder yang merupakan satu paket dengan data seismik yang didapat dari badan Bureau of Economic Geology Texas, USA. Total sumur yang terdapat di dalam wilayah seismik pada penelitian ini berjumlah 38 sumur. Daftar data log yang tersedia pada penelitian ini untuk setiap sumur yang berisi nama sumur, nomor API, dan koordinat. Data log yang dibutuhkan dalam proses inversi dalam satu sumur adalah $p$-wave, density, gamma ray, dan checkshot akan tetapi hanya ada dua sumur yang memiliki empat data log tersebut, yaitu sumur B Yates 18D, dan B Yates 11 sehingga proses inversi akan menggunakan dua sumur ini. Data log yang lain seperti resistivitas, neutron porosity, dan SP dapat digunakan sebagai parameter dalam mengidentifikasi batuan reservoar dan keberadaan hidrokarbon.

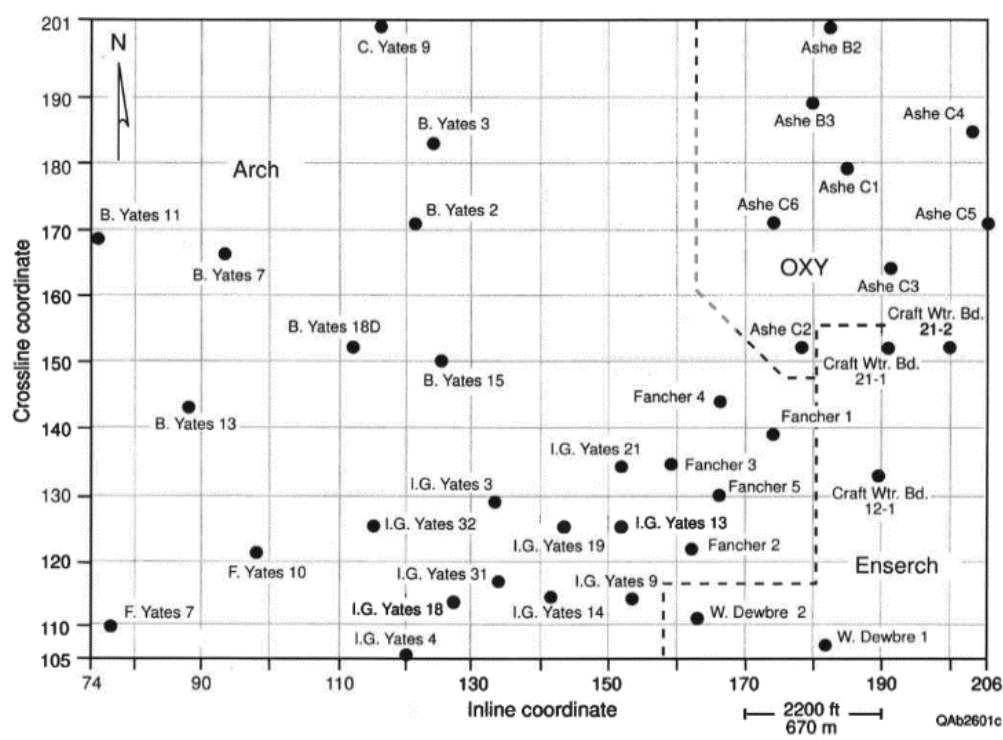

Gambar 1. Detail wilayah penelitian (base map) pada Lapangan Boonsville

Data seismik hanya dapat memperlihatkan kontras nilai impedansi akustik antar lapisan sehingga dapat digunakan untuk menentukan horizon/kemenerusan lapisan bawah permukaan ${ }^{[6]}$. Untuk menambah resolusi vertikal data seismik maka perlu dikontrol oleh data $\log$ yang memiliki resolusi vertikal lebih tinggi dibandingkan dengan data seismik. Kondisi lapisan bawah permukaan yang didapat dari data $\log$ kemudian akan dimasukkan ke dalam volume seismik untuk mengetahui posisi setiap horizon. Proses memasukkan data log yang berupa domain kedalaman $(\mathrm{ft} / \mathrm{m})$ untuk masuk ke dalam volume seismik yang berupa domain waktu $(s)$ dengan memanfaatkan data checkshot disebut seismic well tie.

Setelah data log masuk ke dalam volume seismik maka dapat dibentuk synthetic seismogram/trace synthetic yang didapat dari konvolusi koefisien refleksi dengan wavelet. Koefisien refleksi didapat dari perkalian antara data $\log$ kecepatan gelombang $P$ dengan densitas yang berupa impedansi akustik, sedangkan wavelet didapat dari proses ekstraksi trace seismik pada seluruh volume seismik ${ }^{[7]}$. Synthetic seismogram merupakan permodelan dari data seismik yang akan membawa informasi berupa impedansi akustik dari data log ke seluruh volume seismik sehingga perlu dilakukan korelasi terhadap data seismik asli ${ }^{[8]}$. Korelasi berupa penyamaan kedalaman setiap peak/through yang terdapat pada trace synthetic dengan trace seismik. Semakin mirip trace synthetic dengan trace seismik maka nilai korelasi akan mendekati 1 . Selanjutnya, apabila korelasi sudah baik (nilai korelasi lebih dari 0,6) yang membuat trace synthetic mirip dengan trace seismik maka sudah dapat dilakukan proses picking horizon. Picking horizon yaitu mencari kemenerusan suatu lapisan 
pada volume seismik dengan bantuan data log berupa marker. Picking horizon perlu dilakukan untuk mencari lapisan yang mengandung batuan reservoar berdasarkan studi geologi.

Pembuatan model awal digunakan sebagai acuan untuk inversi yang mendekati data impedansi akustik yang sebenarnya dengan memilih parameter inversi yang optimum. Pembuatan model awal ini dilakukan dengan cara mengubah Synthetic seismogram menjadi impedansi akustik kemudian membandingkannya dengan impedansi akustik yang didapat dari data log. Parameter optimum didapat apabila nilai impedansi akustik dari synthetic seismogram semakin mendekati nilai impedansi akustik dari data log. Setelah parameter optimum didapat maka parameter tersebut akan digunakan untuk melakukan inversi pada trace synthetic yang lainnya sehingga didapat persebaran impedansi akustik pada seluruh volume seismik.

Pembuatan peta porositas bertujuan untuk memprediksi sebaran porositas yang terdapat pada volume seismik. Pembuatan peta porositas dilakukan dengan cara membuat model regresi linear yang menghubungkan variabel porositas dari data log dengan nilai impedansi akustik hasil inversi pada lokasi data $\log$ porositas tersebut berada ${ }^{[3]}$. Hasil dari pembuatan model regresi linier ini adalah suatu persamaan yang dapat digunakan untuk memprediksi besar porositas di setiap lokasi dalam volume seismik.

Interpretasi dilakukan pada data seismik dan hasil inversi impedansi akustik. Interpretasi penelitian ini difokuskan pada kemenerusan formasi Caddo dan Vineyard. Hasil inversi impedansi akustik pada volume seismik dipotong secara horizontal mengikuti kemenerusan dua formasi tersebut sehingga akan terlihat penampang horizontal nilai impedansi akustik pada masing-masing lapisan. Pencarian sebaran batuan reservoar (clean sandstone/batu pasir) dilihat berdasarkan besar cutoff/rentang nilai impedansi akustik batu pasir pada masing-masing lapisan. Besar cutoff impedansi akustik didapatkan dari crossplot data log berupa Density, p-impedance (Impedansi Akustik/AI), dan gamma-ray. Crossplot berfungsi untuk memisahkan batu pasir dengan batu serpih berdasarkan rentang nilai impedansi akustik $^{[9]}$. Batu serpih akan menunjukkan respon nilai Density, p-impedance, dan gammaray lebih besar daripada batu pasir ${ }^{[10]}$. Untuk menambah informasi maka dilakukan analisis secara kualitatif pada data log yang terdapat di sekitar zona yang diprediksi sebagai zona potensial. Sehingga nantinya dapat diketahui apakah zona tersebut terisi oleh hidrokarbon atau tidak. Jika demikian, apabila terdapat cadangan hidrokarbon maka zona target tersebut merupakan zona prospek hidrokarbon.

\section{HASIL DAN PEMBAHASAN}

\section{Hasil Crossplot P Impedance, Density, dan Gamma Ray}

Berikut hasil analisis crossplot dengan p-impedance $(A I)$ pada sumbu $\mathrm{x}$, densitas pada sumbu y, dan gamma ray pada variasi warna titik dengan Gambar 2 untuk formasi Caddo dan Gambar 3 untuk formasi Vineyard. Pada Gambar 2 dan Gambar 3 daerah dengan warna latar kuning diprediksi sebagai batuan clean sand karena memiliki nilai gamma ray yang dominan rendah dan ditambah (pada lapisan Vineyard) memiliki nilai densitas yang rendah, daerah dengan warna latar abu-abu diprediksi sebagai shale karena memiliki nilai gamma ray dominan tinggi ditambah densitas yang tinggi, daerah latar merah muda diprediksi sebagai daerah shaly sand. 


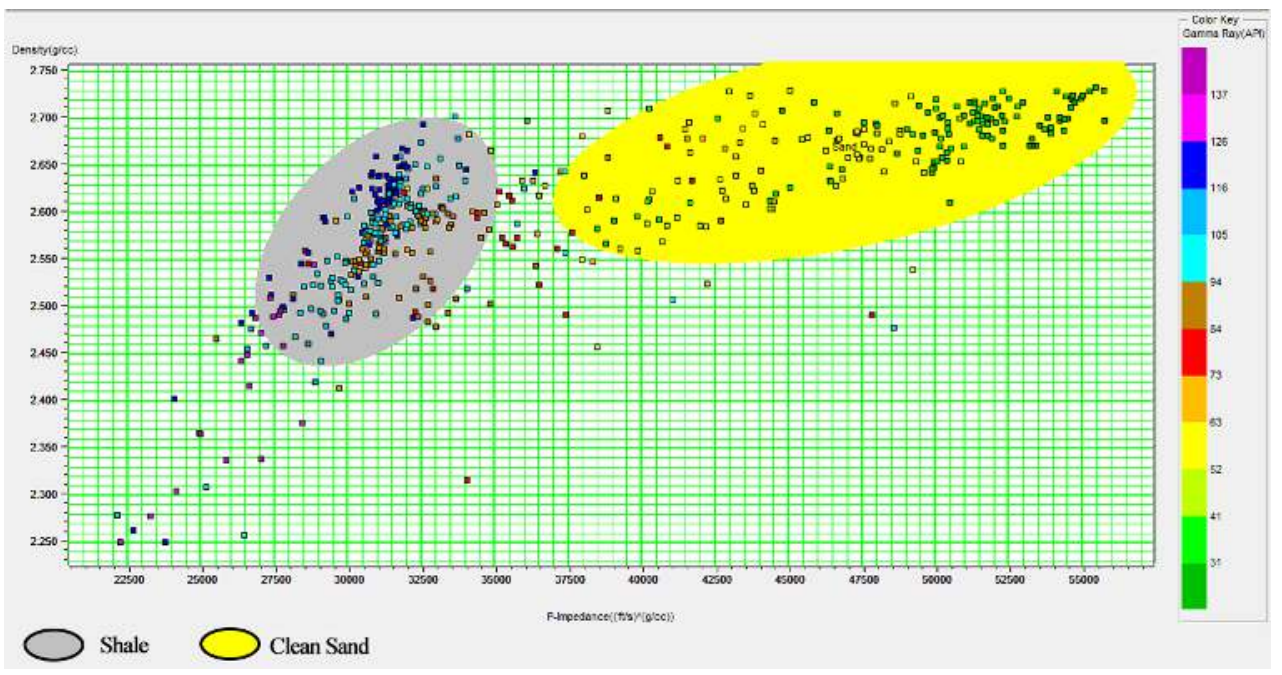

Gambar 2. Hasil crossplot p-impedance, density dan gamma ray pada formasi Caddo

Grafik crossplot antara P-impedance, desnity mengasumsikan adanya hubungan antara kedua parameter tersebut. Asumsi hubungan empiris antara dua parameter ini dapat digunakan untuk menentukan cutoff AI clean sand. Berdasarkan hasil perhitungan cutoff AI clean sand diperoleh adalah $37500(\mathrm{ft} / \mathrm{s})(\mathrm{gr} / \mathrm{cc})$ untuk formasi Caddo dan $32500(\mathrm{ft} / \mathrm{s})$ (gr/cc) untuk formasi Vineyard. Berdasarkan Nilai cutoff AI untuk formasi Caddo dan Vineyard yang diperoleh dijadikan acuan bahwa nilai $A I$ dibawah nilai cutoff tidak memiliki prospek hidrokarbon untuk diproduksi, sehingga diperoleh:

a) Nilai cutoff AI clean sand pada formasi Caddo adalah: $38000-55500(\mathrm{ft} / \mathrm{s})(\mathrm{gr} / \mathrm{cc})$

b) Nilai cutoff AI clean sand pada formasi Vineyard adalah: $33000-37500(\mathrm{ft} / \mathrm{s})$ $(\mathrm{gr} / \mathrm{cc})$

Tujuan akhir dari crossplot ini digunakan untuk membedakan sebaran clean sand, shaly sand dan shale pada penampang $A I$ di formasi Caddo dan Vineyard ${ }^{[11]}$.

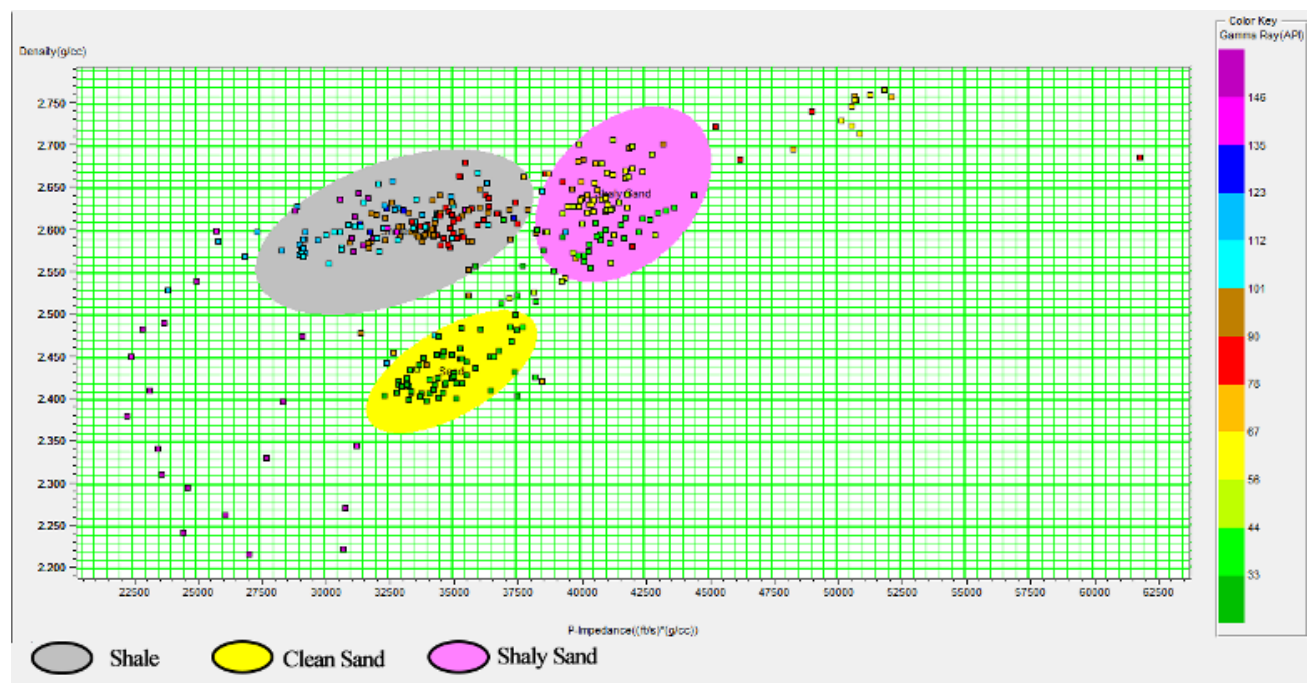

Gambar 3. Hasil crossplot p-impadance density dan gamma ray pada formasi Vineyard 


\section{Formasi Top Caddo}

Sebaran impedansi akustik dan porositas pada Top Caddo dapat dilihat pada Gambar 4. Pada Gambar 4 bagian atas merupakan sebaran impedansi akustik dan bagian bawah adalah sebaran porositas. Pada sebaran $A I$ terlihat warna merah mewakili nilai $A I$ yang tinggi (42000 (ft/s) (gr/cc)) kemudian menurun hingga terlihat warna ungu yang mewakili nilai $A I$ yang rendah $(28000(\mathrm{ft} / \mathrm{s})(\mathrm{gr} / \mathrm{cc}))$.

Pada sebaran porositas terlihat warna hijau muda mewakili nilai porositas besar $(27 \%)$ kemudian menurun hingga terlihat warna ungu muda yang mewakili nilai porositas (12\%). Berdasarkan analisis crossplot pada Top Caddo, nilai cutoff $A I$ untuk clean sand cukup besar yaitu: 38000 - $55500(\mathrm{ft} / \mathrm{s})(\mathrm{gr} / \mathrm{cc})$. Lapisan yang menyimpan kandungan gas di interpretasikan memiliki nilai neutron porosity yang rendah yang disebut dengan gas effect. Hasil prediksi sebaran porositas yang digunakan didalam penelitian ini didapatkan dari data $\log$ neutron porosity dari sumur B Yates $18 \mathrm{D}$ sehingga fenomena gas effect dapat di masukkan kedalam salah satu faktor pencarian hidrokarbon pada penelitian ini. Dari gambar 4 sebaran $A I$ dan porositas terlihat terdapat beberapa lokasi yang memiliki nilai $A I$ tinggi disertai nilai porositas yang rendah. Lokasi-lokasi tersebut ditandai dalam lingkaran hitam dengan total terdapat 4 zona. Zona 1 disekitar inline $76-93$ dan xline $180-200$, Zona 2 disekitar inline $74-85$ dan xline 140 - 165, Zona 3 disekitar inline 140 - 150 dan xline 167 - 172, Zona 4 disekitar inline 180 - 200 dan xline 135-170. Didalam/disekitar zona tersebut terdapat sumur yang memiliki data log untuk di analisis kualitatif guna untuk memprediksi kandungan dan litologi formasi Caddo daerah tersebut. Terdapat 2 sumur yaitu B Yates 11 yang berada diwilayah barat dan Ashe C3 yang berada pada wilayah timur.

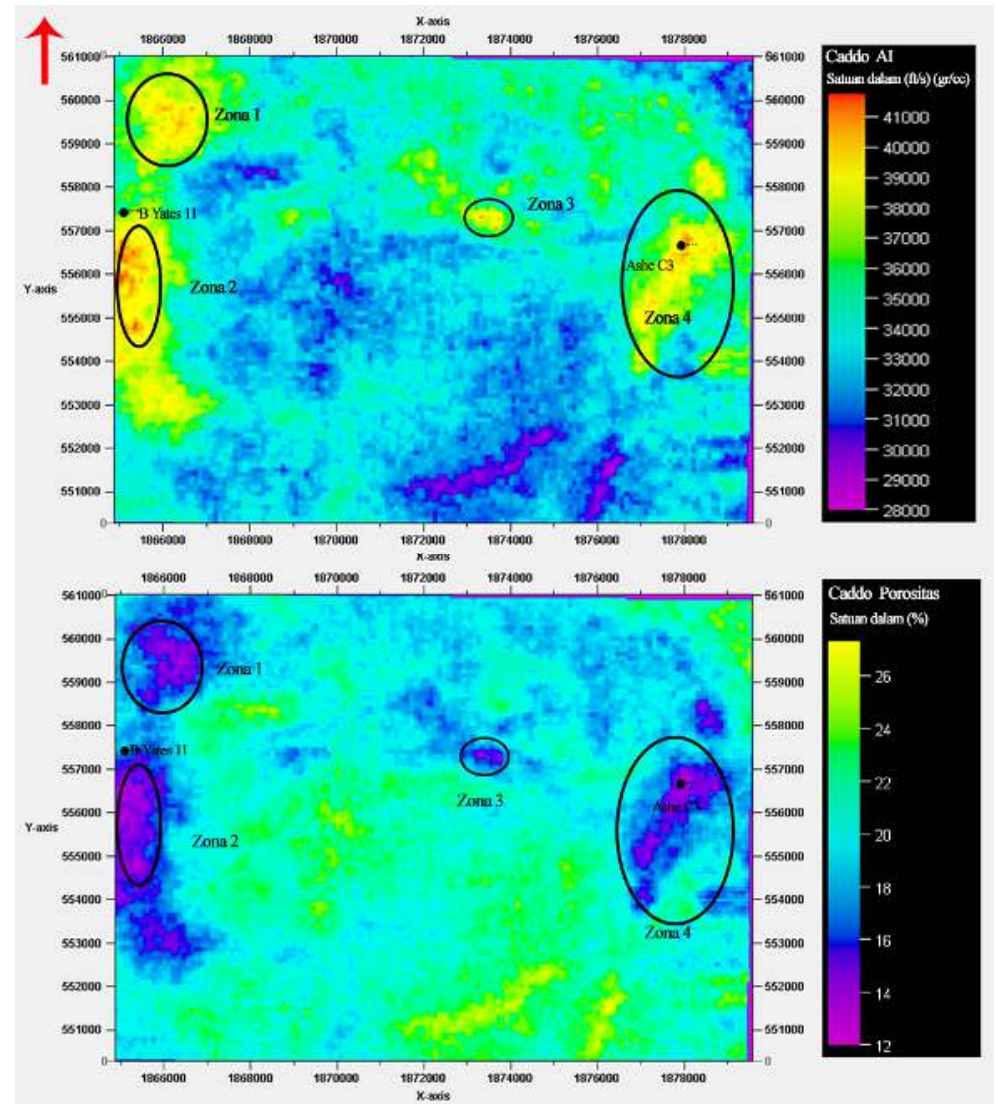

Gambar 4. Sebaran impedansi akustik (atas) dan sebaran porositas (bawah) pada formasi Top Caddo 


\section{Formasi Top Vineyard}

Gambar sebaran impedansi akustik dan porositas pada Top Vineyard dapat dilihat pada Gambar 5. Pada Gambar 5 bagian atas merupakan sebaran impedansi akustik dan bagian bawah adalah sebaran porositas. Pada sebaran $A I$ terlihat warna merah mewakili nilai $A I$ yang tinggi $(45000(\mathrm{ft} / \mathrm{s})(\mathrm{gr} / \mathrm{cc}))$ kemudian menurun hingga terlihat warna ungu yang mewakili nilai $A I$ yang rendah $(28000(\mathrm{ft} / \mathrm{s})(\mathrm{gr} / \mathrm{cc}))$. Pada sebaran porositas terlihat warna hijau muda mewakili nilai porositas besar $(27 \%)$ kemudian menurun hingga terlihat warna ungu muda yang mewakili nilai porositas (12\%). Berdasarkan analisis crossplot pada formasi Vineyard, nilai cutoff AI untuk clean sand yaitu: 33000 - 37500 (ft/s) (gr/cc).

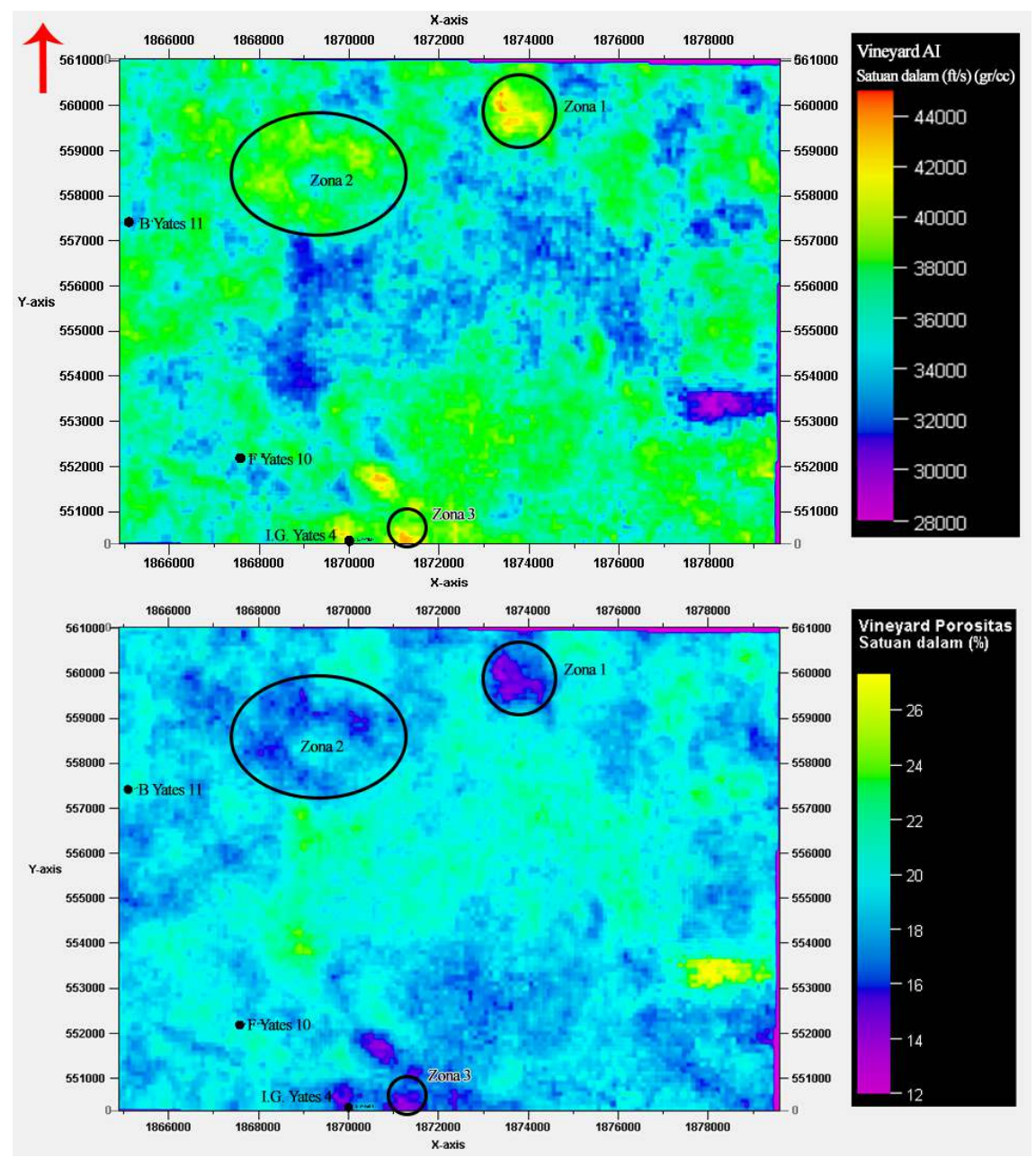

Gambar 5. Sebaran impedansi akustik (atas) dan sebaran porositas (bawah) pada formasi Top Vineyard

Nilai cutoff AI clean sand ini berhimpit dengan nilai cutoff AI shale yang memiliki nilai $28500-38000(\mathrm{ft} / \mathrm{s})(\mathrm{gr} / \mathrm{cc})$ yang artinya sulit untuk memisahkan lapisan clean sand dengan shale hanya berdasarkan peta sebaran impedansi akustik. Pada Gambar 5 terlihat 3 zona yang memiliki nilai $A I$ tinggi disertai nilai sebaran porositas yang rendah. Nilai $A I$ tinggi berdasarkan crossplot diduga sebagai shaly sand yang artinya diprediksi dalam 3 zona ini memiliki shaly sand yang mengandung gas. 3 zona tersebut adalah Zona 1 disekitar inline 140 - 160 dan xline 180 - 200, Zona 2 disekitar inline 98 - 120 dan xline 169 - 190, Zona 3 disekitar inline 130 - 140 dan xline 105 - 115. Didalam/disekitar zona tersebut terdapat 
sumur yang memiliki data $\log$ untuk di analisis kualitatif guna untuk memprediksi kandungan dan litologi formasi Vineyard daerah tersebut. Terdapat 3 sumur yaitu B Yates 11 yang berada diwilayah barat, F Yates 10 dan I.G Yates 4 yang berada pada wilayah selatan. Hasil analisis kualitatif sumur B Yates 11.

\section{KESIMPULAN}

Hasil analisis crossplot ditemukan nilai cutoff AI clean sand stone pada formasi Caddo sebesar 38000 - 55500 (ft/s) (gr/cc), dan formasi Vineyard sebesar 33000 - $37500(\mathrm{ft} / \mathrm{s})$ (gr/cc). Pada Top Caddo ditemukan 4 zona yang diprediksi mengandung gas dengan reservoar berupa sand stone. Hal tersebut teridikasi dari gambar penampang $A I$ yang memperlihatkan nilai $A I$ yang besar pada 4 zona tersebut. Hasil dari gambar penampang porositas memperlihatkan nilai porositas yang kecil di dalam 4 zona tersebut yang diprediksi mengandung gas. Hasil analisis kualitatif sumur B Yates 11 dan Ashe C3 juga memprediksi bahwa di daerah 4 zona tersebut mengandung gas pada formasi Caddo. Pada Top Vineyard ditemukan 3 zona yang diprediksi juga mengandung gas dengan reservoar berupa shaly sand. Hal tersebut diprediksi karena di dalam 3 zona tersebut memiliki nilai $A I$ yang tinggi sedangkan besar porositasnya rendah. Hasil analisis kualitatif sumur B Yates 11, F Yates 10, dan I.G. Yates 4 juga memprediksi bahwa di daerah 3 zona tersebut mengandung gas pada formasi Vineyard.

\section{DAFTAR PUSTAKA}

1 Sanjaya, N. Debby. 2014. Analisis Sifat Fisis Reservoar Menggunakan Metode Seismik Inversi Accoustic Impedance (AI) dan Multiatribut (Studi Kasus Lapangan F3). Skripsi. Institut Teknologi Sepuluh Nopember. Surabaya.

2 Mushoddaq Mochammad. 2012. Deteksi Lapisan Hidrokarbon Dengan Metode Inversi Impedansi Akustik dan EMD (Empirical Mode Decomposition) Pada Formasi AIr Benakat Lapangan "X”. Skripsi. Institut Teknologi Sepuluh Nopember. Surabaya.

3 Aamer, A. A. 2013. 3D seismic data interpretation of Boonsville Field, Texas. Masters Theses. Missouri University of Science and Technology. USA.

4 Zain, N.M., \& Lestari, W. 2017. Karakteristik Reservoar Menggunakan Aplikasi Seismik Atribut dan Inversi Seismik Impedansi Akustik, Studi Kasus Lapangan Teapot Dome, Wyoming. Jurnal Sains dan Seni POMITS, Vol. 6 No.2.

5 Primaditaningtyas, W. 2013. Evaluasi Prospektivitas Menggunakan Pendekatan Impedansi Akustik: Studi Kasus Lapangan Penobscot, Nova Scotia, Kanada. Skripsi. Universitas Indonesia. Jakarta.

6 Yilmaz, O. 2001. Seismic Data Analysis: Processing Inversion, and Interpretation of Seismic Data. SEG. Tulsa. USA.

7 Intan, P. A. 2014. Integrasi Seismik Inversi Acoustic Impedance (AI) dan Elastic Impedance (EI) Untuk Karakterisasi Reservoar, Studi Kasus: Lapangan Muon. Skripsi. Institut Teknologi Sepuluh Nopember. Surabaya.

8 Sheriff, R. E. 1995. Exploration Seismology, 2nd Edition. University of Houston.

9 Telford W.M, L.P. Geldart, R.E. Sheriff. 1992. Applied Geophysics Second Edition. Cambridge University Press. Cambridge, UK.

10 Sheriff, R. E. 1995. Exploration Seismology, 2nd Edition. University of Houston.

11 Ikelle Luc T., \& Amundsen, L. 2005. Introduction to Petroleum Seismology. Society of Exploration Geophysicists. USA. 